\title{
Rediscovery and notes on Brachystelma maculatum (Apocynaceae)
}

\author{
K. Prasad ${ }^{1}$ and P. Venu ${ }^{2 *}$ \\ ${ }^{1}$ Central National Herbarium, Botanical Survey of India, Howrah, West Bengal - 711 103, India. \\ ${ }^{2}$ Environment Protection Training and Research Institute, Gachibowli, Hyderabad - 500032 , India. \\ *Email: pvenu.bsi@gmail.com
}

\begin{abstract}
Brachystelma maculatum Hook.f. was rediscovered far from the type locality after a century in Nallamala forests of Andhra Pradesh. Its taxonomic identity and morphological affinity with $B$. bourneae, $B$. rangacharii and $B$. nallamalayanum are discussed. An enhanced description of $B$. maculatum, its conservation status and an updated key to delineate the above species are presented.
\end{abstract}

Keywords: Conservation, Endemism, Geophytes, Rarity, Taxonomy.

\section{Introduction}

The genus Brachystelma R.Br. in general project three innate difficulties in documentation in floristic accounts. Its members are essentially geophytes with narrow endemism and short span of appearance. They exhibit slender habit and small flowers and conceal themselves in grassy bushes and taxonomists need extra watchfulness in their collection. Specimen collections for majority species remained low for this reason in different herbaria. Their inclusion and documentation was based on single or very few collections in Indian floras. In some cases, even the available specimens defy any detailed study as their flowers are small and significant taxonomic features such as corolla ornamentation/indumentum and corona structure get lost in specimen processing in herbaria. The protologues of a few taxa which had appeared in the mid of $19^{\text {th }}$ century were truly imperfect as for the description is concerned owing to limited number of specimens as well their poor quality (deprived of significant taxonomic features). Thus, protologues with poor quality types at times will not allow adequate leverage to taxonomists to identify and authenticate later collections of the taxa concerned. In some instances, specimens with pencil illustrations of the authors on the sheet proved quite constructive in realizing the diagnostics and linking it to protologues. Hooker (1883) had included seven new species, all described by him, in the Flora of British India. He had stated that his descriptions are "very imperfect" for the stated reasons. As of today, 29 species have been reported from India and all are endemic. Many of them are represented by type collections alone (Venu \& Prasad, 2015) and some do pose problems in identification/ authentication. Studies based on molecular taxonomy have shown that Indian Brachystelma species and African ones are situated in two different subclades, but both are nested within Ceropegia, making Ceropegia, paraphyletic (Surveswaran et al., 2009; Bruyns et al., 2015). But Bruyns et al. (2017) concluded that Ceropegia is monophyletic and merged the genus Brachystelma under it. Since the generic delimitation still remains controversial, the authors' preferred to retain the traditional classification, keeping Brachystelma as separate genus. Further, the focus of the article is to elaborate on the accurate identity of B. maculatum.

Nothing is more satisfying to explorers involved in Brachystelma taxonomy than could chance upon collecting a rare species and then "rightly identifying" it. A species of Brachystelma was collected in Nallamala forests of Andhra Pradesh, which was later recognized as a rediscovery of $B$. maculatum described by Hooker (1883) about 100 years ago. The authors could arrive to its identity as $B$. maculatum based on a lone type collection of Law (1851-1854) from Canara \& Mysore. Gamble (1922) included the collection of Rangachari from Dimbhum (Coimbatore) in the flora Madras Presidency. These specimens could not be traced till date. Fischer's collection from Talamalai in 
Tamil Nadu (1903) may be regarded as the latest (Field no. 61, CAL!) and included in flora of Tamil Nadu. Not surprisingly, only Law's collection was cited in floras as the specimens of other two collectors were not traceable or of poor quality. Hooker gave a small description, but emphasized three diagnostic features: corolla tube and partly its lobes mottled systematically and prominently, (hence maculatum), the lobes keeled above down the middle and the corona with 5 subulate teeth opposite to and much higher than anthers. The type sheet with figures of corolla (with dotted ornamentation at base of corolla lobes), open corona and pollinia by Hooker convinced the authors beyond doubt that their collection is nothing but B. maculatum! The authors believed that bringing three more near similar species, B. bourneae Gamble, B. rangacharii Gamble and B. nallamalayanum K. Prasad \& B.R. Rao, into deliberation would better clarify diagnostics involved in these species. All four species project similar habit with slender, sturdy and erect stems and long drooping leaves. The well spread specimens on herbarium sheets could hardly give a clue how they look truly in their habitat. The authors have provided a photo plate consisting of its habit and other floral features and an enhanced description based on fresh collection from the Eastern Ghats.

\section{Taxonomy}

Brachystelma maculatum Hook.f., Fl. Brit. India 4: 65. 1883; Blatter, J. Bombay Nat. Hist. Soc. 18: 413. 1908; Gamble, Fl. Madras 851. 1922; Sharma et al., Fl. Karnataka 164. 1984; Srinivasan, Fl. Tamil Nadu Analysis 2: 80. 1987; Jagtap \& N.P. Singh, Fasc. Fl. India 24: 186. 1999.

Type: INDIA, Karnataka, Canara \& Mysore, s.d., J.S. Law s.n (K000820013!).

Fig. 1.

Tuberous herbs, c. $80 \mathrm{~cm}$ high; tubers fusiform. Stem slender, terete, un-branched, glabrous, with watery sap. Leaves sessile, linear or filiform, acute, c. $12 \times 0.2 \mathrm{~cm}$. Inflorescence lateral or axillary, subsessile or shortly pedunculate; cymes 2-3-flowered; bract and bracteoles linear or subulate, acute, glabrous, persistent; bract c. $2 \times 0.5 \mathrm{~mm}$; bracteoles $1 \times 0.2 \mathrm{~mm}$; pedicels filiform, glabrous, c. $9 \mathrm{~mm}$ long. Calyx lobes 5, linear, acute, c. $3 \times 1 \mathrm{~mm}$, pinkish-green, glabrous. Corolla rotate, lemon yellow; tube very short, c. $2 \mathrm{~mm}$ long, orderly and prominently black mottled; lobes 5, c. $2.3 \times 0.2$ $\mathrm{cm}$, broad and ovate at base, narrowed above and tapered at apex, keeled above down the middle, lobe margins above revolute, white hairy; hairs c. 2 $\mathrm{mm}$ long; black mottled ornamentation extends to basal portions of lobes. Corona biseriate vs. corona uniseriate (Meve, 2002, Jagatap \& Singh, 1999), black, c. $2 \mathrm{~mm}$ in diam., glabrous; inter staminal corona 5-angled, cupular, forms continuous ring around pentangular gynostegium; staminal corona 5-lobed; lobes adpressed to back of the anthers, hooded, triangular or subulate, acute or obtuse, $c$. $0.8 \mathrm{~mm}$ long. Pollinia yellow, ellipsoid, c. $0.2 \mathrm{~mm}$ long, pellucid margined, joined by light-brown tubular caudicles to a red-coloured corpuscle. Follicles paired, cylindrical, tapering towards apex, 6-8 cm long; seeds comose, narrowly elliptic.

Flowering \& fruiting: July-September.

Habitat \& ecology: In blackish-red soils among clumps of Cymbopogon coloratus (Hook.f.) Stapf, at 500-600 m elevation.

\section{Distribution: Endemic to South India (Fig. 2).}

Specimens examined: INDIA, Andhra Pradesh, Kurnool district, NSTR, way to Sikharam, $16^{\circ}$ $02^{\prime}$ N, 78 ${ }^{\circ}$ 53' E, 566 m, 02.08.2014, K. Prasad 6414 (CAL! \& BSID!). Tamil Nadu, Coimbatore district, Talamalai, 02.06.1905, C.E.C. Fischer 61 (CAL!).

Conservation status: The species is now represented by four records in restricted areas of Eastern/ Western Ghats. The tubers are good source of food and about 100 individuals were located in Sikharam area. Further explorations in the earlier documented locations are necessary to ascertain its populations. The habitat is prone to seasonal forest fires and also grazing by wild boars. As per the IUCN guidelines (IUCN, 2017), the species is assessed as 'Data Deficient' (DD).

Notes: A key for delimiting B. maculatum with morphologically similar, $B$. bourneae, $B$. rangacharii and $B$. nallamalayanum, is given below. All four species share very similar habit but differ appreciably in floral features (corolla colour, ornamentation, indumentum and corona structure) and thus hold their specific identities. The less known species, B. bourneae and $B$. rangacharii require rediscovery to strengthen the diagnostics.

\section{Key to the species}

1. Cymes less than 5-flowered (usually 2-3flowered........ 2

1. Cymes 5 or more flowered .....................................

2. Corolla tube white mottled; corolla lobes not keeled, retrorse at apex; lobe margins purple 

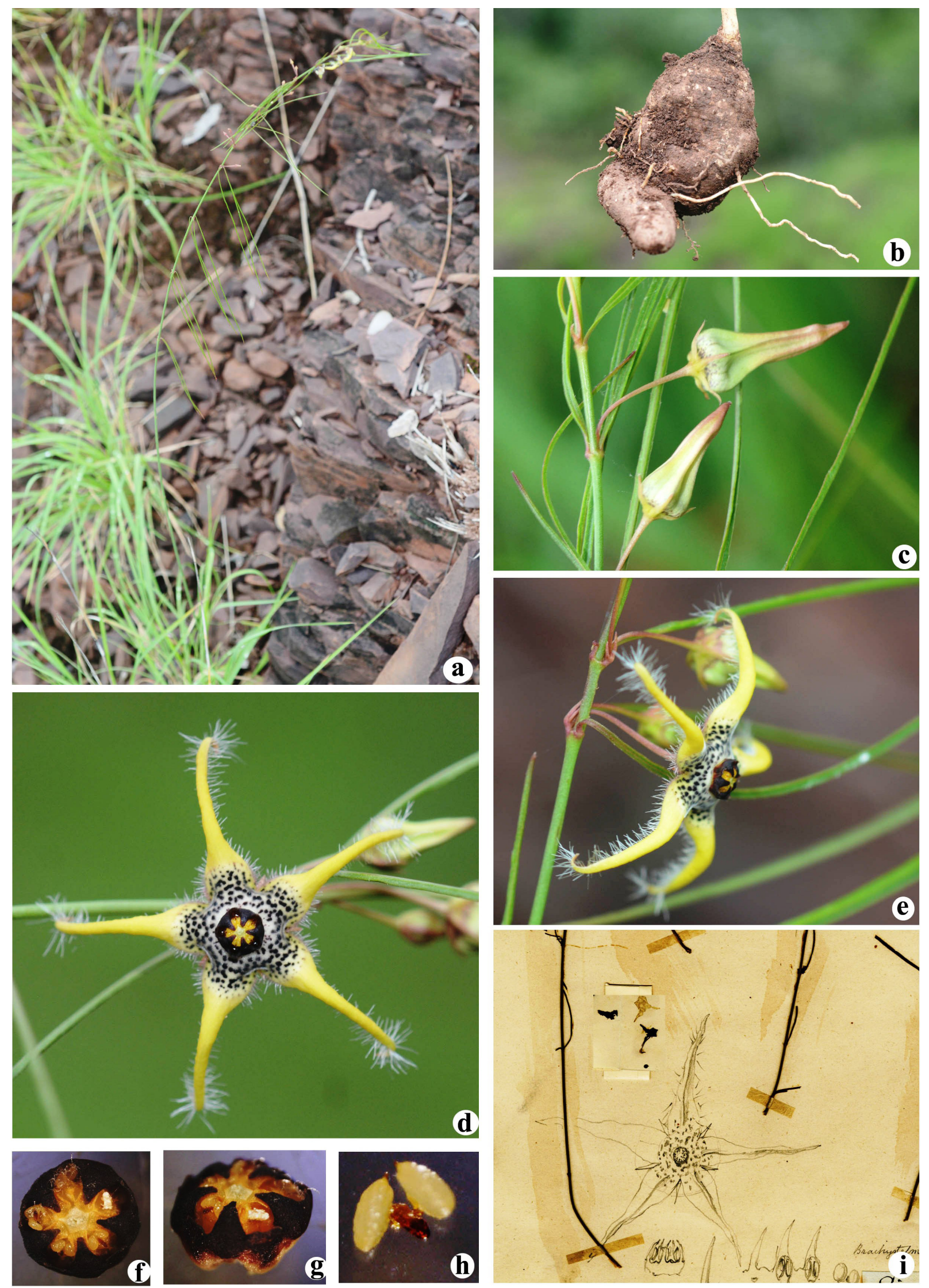

Fig. 1. Brachystelma maculatum Hook. f. a. Habit; b. Tuber; c. Flower buds; d. Flower-front view; e. Flower-side view; f \& g. Corona-top and front view; h. Pollinia; i. Flower sketch on type sheet (K000820013). 

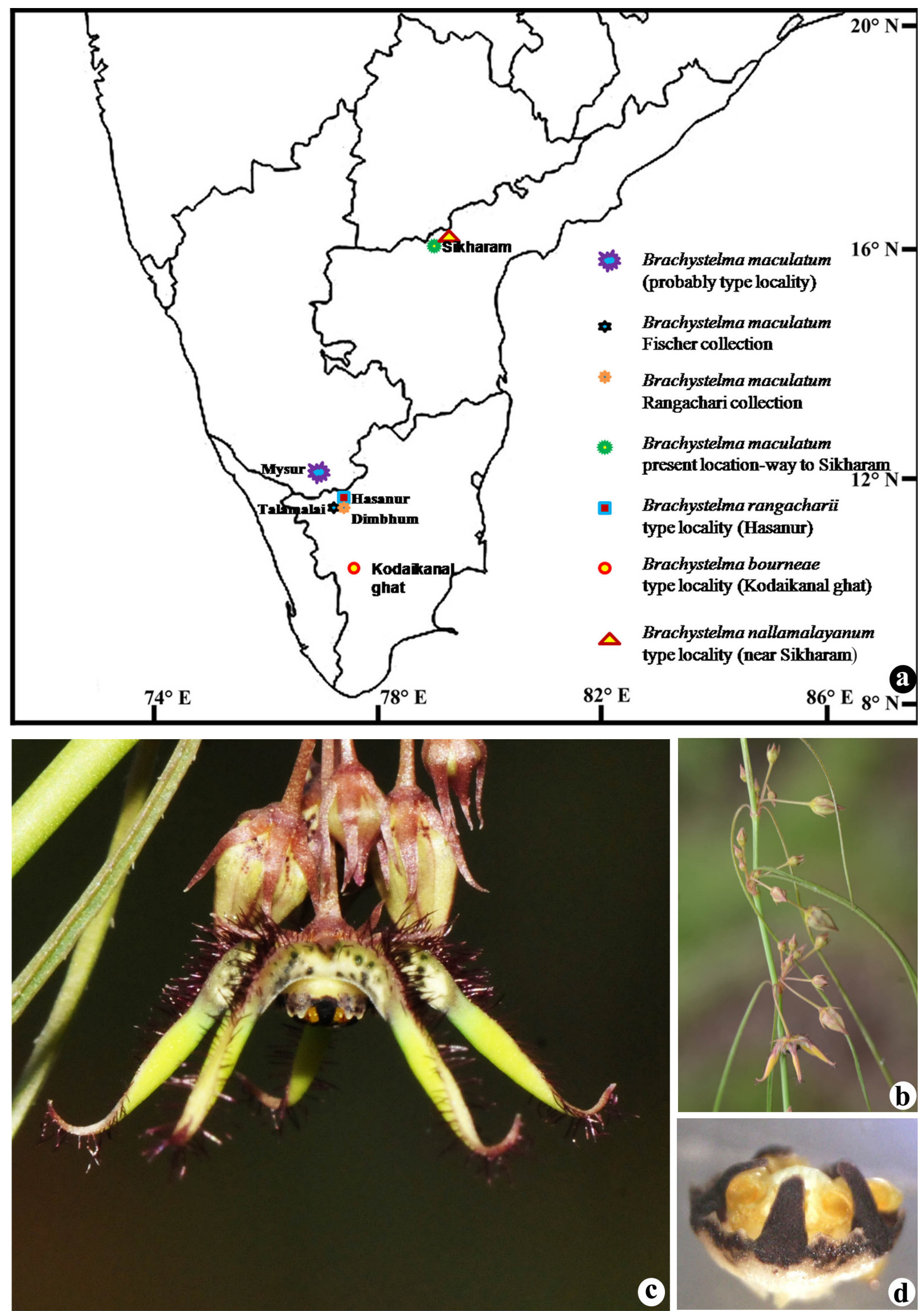

Fig. 2. a. Known locations of Brachystelma species in South India; b. B. nallamalayanum flowering twig; c. Flower cluster close up; d. Corona. 
hairy; interstaminal corona bilobed at each angle . B. bourneae

2. Corolla tube black mottled; corolla lobes keeled above down the middle, not retrorse at apex; lobe margins white hairy or rarely with purple hairy; interstaminal corona not bilobed at each angle B. maculatum

3. Tubers oblong; leaves verticillate (in 3s) or opposite; cymes sessile; corolla pale white; lobes white villous within; interstaminal corona undulate at each angle. B. rangacharii

3. Tubers ovoid or sub-globose; leaves invariably opposite; cymes shortly peduncled; corolla yellow or yellowish green; lobes pink hairy along the margins; interstaminal corona bilobed at each angle B. nallamalayanum

\section{Acknowledgements}

The authors are thankful to the Director, Botanical Survey of India, Kolkata and the Director General, EPTRI for facilities and Andhra Pradesh Forest Department for permission to conduct field works. $\mathrm{KP}$ is thankful to SERB (DST, New Delhi) and PV to CSIR (New Delhi) for financial assistance.

\section{Literature Cited}

Bruyns, P.V., Klak, C. \& P. Hanacek 2015. Recent radiation of Brachystelma and Ceropegia (Apocynaceae) across the Old World against a background of climatic change. Molec. Phylogenet. Evol. 90: 49-66.

Bruyns, P.V., Klak, C. \& P. Hanacek 2017. A revised, phylogenetically-based concept of Ceropegia (Apocynaceae). S. African J. Bot. 112: 399-436.
Gamble, J.S. 1922. Flora of the Presidency of Madras. Vol. 2. Adlard \& Son, London. pp. 850-852.

Hooker, J.D. 1883. Flora of British India. Vol. 4. L. Reeve \& Co., London. pp. 64-66.

IUCN Standards and Petitions Subcommittee 2017. Guidelines for Using the IUCN Red List Categories and Criteria, Version 13. Prepared by the Standards and Petitions Subcommittee of the IUCN Species Survival Commission. Available from: http://jr.iucnredlist.org/ documents/RedListGuidelines.pdf, (accessed 28.03.2017).

Jagtap, A.P. \& N.P. Singh 1999. Fascicles of Flora of India, Fascicle 24. Botanical Survey of India, Kolkata. pp. 178-190.

Meve, U. 2002. Brachystelma. In: Albers, F. \& U. Meve (eds.), Illustrated Handbook of Succulent Plants: Asclepiadaceae. Spinger-Verlag, Berlin, Heidelberg, New York. pp. 20-46.

Surveswaran, S., Kamble, M.Y., Yadav, S.R. \& M. Sun 2009. Molecular phylogeny of Ceropegia (Asclepiadoideae, Apocynaceae) from Indian Western Ghats. Pl. Syst. Evol. 281: 51-63.

Venu, P. \& K. Prasad 2015. The existential crisis in Indian Brachystelmas (Apocynaceae). Curr. Sci. 109(4): 680-682.

Received: 03.02.2018

Revised and Accepted: 22.08.2018 